\title{
Status Kualitas Air Pesisir Bukit Ameh di Kawasan Ekonomi Khusus Mandeh di Kabupaten Pesisir Selatan
}

\section{Status of Bukit Ameh Coastal Water Quality in Mandeh Economic Special Zone in Pesisir Selatan Regency}

\author{
YUDHI SOETRISNO GARNO \\ Pusat Teknologi Lingkungan, Badan Pengkajian dan Penerapan Teknologi \\ Gedung 820 Geostech, Kawasan Puspiptek Serpong, Tangerang Selatan, Banten \\ Email: yusoegarno@gmail.com
}

\begin{abstract}
The Bukit Ameh (Mandeh) area of Pesisir Selatan Regency, West Sumatra, has a potentially unique landscape as a tourist attraction. Therefore, this area will be developed into a special economic area for tourism. However, for doing so, there will be various activities performed there that could affect the environmental conditions there. Accordingly, this study was carried out to determine the quality status of the Bukit Ameh coastal waters to anticipate the impact of various special economic areas for tourism development activities in the future. This study's results indicate that the nutrient content of Bukit Ameh waters has exceeded the Quality Standards. The coastal waters of Bukit Ameh, inhabited by 23 species of phytoplankton from 4 classes with abundance ranging from 795,183 to $3,909,750 \mathrm{ind} / \mathrm{m}^{3}$. Phytoplankton community is dominated by Trichodesmium sp. with the highest population of 2,162,994 ind $/ \mathrm{m}^{3}$ or 73.2 percent of total abundance. In addition to Trichodesmium sp., on the coast of Bukit Ameh also found Ceratium sp., Dinophysis sp., and Peridinium sp., which can trigger the Harmful Algal Bloom which is poisonous and can kill other organisms that eat it. Comparing dissolved nutrients and abundance of phytoplankton in several coastal does not show a positive correlation, in the sense that the more fertile the waters, the higher the abundance of phytoplankton.
\end{abstract}

Keywords: water quality, coastal, abundance, phytoplankton

\section{ABSTRAK}

Kawasan Bukit Ameh (Mandeh) Kabupaten Pesisir Selatan, Sumatra Barat, merupakan salah satu kawasan pariwisata yang memiliki keunikan bentang alam sebagai daya tarik wisata, sehingga kawasan ini akan dikembangkan menjadi Kawasan Ekonomi Khusus (KEK) Pariwisata. Terkait hal ini, akan ada kegiatan pengembangan ekonomi yang memiliki potensi mempengaruhi kondisi lingkungan di sana. Oleh karena itu, untuk mengantisipasi dampak dari berbagai kegiatan di KEK pariwisata di masa datang, maka dilaksanakan penelitian yang bertujuan untuk mengetahui status kualitas perairan pesisir Bukit Ameh. Hasil penelitian ini mengisaratkan bahwa kandungan nutrien perairan Bukit Ameh telah melampaui Baku Mutu. Perairan pesisir Bukit Ameh, dihuni oleh 23 jenis fitopankton dari 4 kelas dengan kelimpahan berkisar antara 795.183-3.909.750 ind $/ \mathrm{m}^{3}$. Komunitas fitoplankton didominasi oleh Trichodesmium $\mathrm{sp}$. dengan populasi tertinggi $2.162 .994 \mathrm{ind} / \mathrm{m}^{3}$ atau $73,2 \%$ kelimpahan total. Selain Trichodesmium sp., di pesisir Bukit Ameh juga ditemukan juga Ceratium sp., Dinophysis sp. dan Peridinium sp. yang dapat memicu terjadinya Harmful Algal Bloom yang beracun dan dapat membunuh organisme lain yang memangsanya. Pembandingan nutrien terlarut dan kelimpahan fitoplankton di beberapa perairan pesisir tidak menunjukkan adanya korelasi positif, dalam arti bahwa makin subur peralihan makin tinggi kelimpahan fitoplankton.

Kata kunci: kualitas perairan, pesisir, kelimpahan, fitoplankton

\section{PENDAHULUAN}

\subsection{Latar Belakang}

Kawasan wisata Mandeh merupakan salah satu kawasan pariwisata yang terletak di Kabupaten Pesisir Selatan Provinsi Sumatera Barat yang memiliki keunikan bentang alam sebagai Daya Tarik Wisata (DTW). Kawasan Mandeh merupakan salah satu Kawasan Pengembangan Pariwisata Nasional (KPPN) Pesisir Selatan dan sekitarnya sebagaimana telah tercantum Dalam Lampiran PP Nomor 50 Tahun 2011, dan telah pula ditetapkan sebagai Kawasan wisata utama dalam Perda Propinsi Sumatera Barat Nomor 3 Tahun 2014 tentang Rencana Induk Pembangunan Kepariwisataan Provinsi Sumatera Barat. Selajutnya melalui surat pernyataan Bupati Pesisir Selatan nomor 050/289.VI/Bappeda-PS/2016 tertanggal 24 Juni 2016, Kawasan Bukit Emas (Bukit Ameh) di Nagari Carocok Anau Ampang Pulai di Kecamatan Koto XI Tarusan yang merupakan 
bagian dari Kawasan Mandeh diusulkan sebagai Kawasan Ekonomi Khusus (KEK) Pariwisata

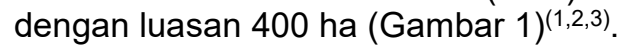

Dalam dokumen Studi Kelayakan dan Financial Feasibility Study KEK Pariwisata Mandeh (Bukit Ameh) yang disusun oleh Pemerintah Provinsi Sumatera Barat disebutkan bahwa di lahan KEK Pariwisata yang luasnya 400 ha tersebut akan dikembangkan kawasan wisata dengan konsep ekowisata bahari(4). Kegiatan pembangunan tersebut, antara lain amenitas seperti resort dan hotel; sarana wisata seperti MICE, gedung pertemuan, pertokoan, dan restoran; mangrove, pantai, dan alam; serta aksesibilitas seperti TPS dan water treatment, jaringan listrik dan menara BTS, dermaga dan area parkir perahu. Kawasan seluas 400 Hektar tersebut secara fisik berada di Bukit Ameh, dan karena studi ini terbatas pada perairan pesisir Bukit Ameh, maka untuk selanjutnya dalam dokumen studi ini menggunakan istilah Bukit Ameh.

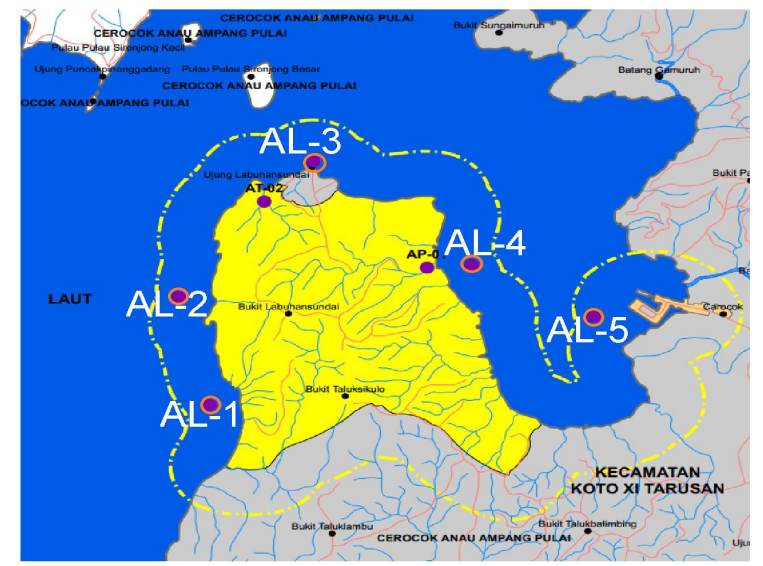

Gambar 1. Kawasan Ekonomi Khusus Pariwisata Mandeh (warna kuning). AL01-AL05 = titik sampling

Berbagai kegiatan pembangunan fisik yang akan dilaksanakan dalam masa kontruksi sudah tentu akan membuang limbah yang mencemari pesisir di sekitarnya. Selanjutnya pada masa operasi, akan ada berbagai aktifitas yang akan menghasilkan limbah secara berkelanjutan, yang akhirnya juga akan masuk dan mencemari perairan pesisir. KEK Pariwisata Mandeh yang berada di Bukit Ameh tersebut akan dikembangkan menjadi kawasan wisata dengan konsep ekowisata bahari. Pada umumnya kawasan wisata bahari akan menghasilkan limbah yang didominasi oleh limbah organik, yang segera terurai menghasilkan nutrien. Peningkatan nutrien yang berkelanjutan dalam perairan akan dapat menyebabkan terjadinya eutrofikasi. Secara alamiah, eutrofikasi pada awalnya akan dapat meningkatkan produktivitas perairan; tetapi jika nutrien yang masuk berlebihan akan menyebabkan terjadinya algal bloom $^{(5,6,7)}$.

Fenomena algal bloom tidak dikehendaki karena selain dapat mengakibatkan terjadinya penurunan oksigen secara drastis, juga jika algal bloom tersebut didominasi oleh fitoplankton dari kelas Dinoflagellata, Bacillariophyceae (Nitzschia pungens $f$. multiseries), dan Cyanophyceae (Trichodesmium erythraeum), akan berbahaya karena diantara jenis fitoplankton tersebut mengandung zat yang beracun bagi organisme lain dan manusia. Fenomena algal bloom beracun tersebut dikenal sebagai Harmful Algal Blooms atau $\mathrm{HABs}^{(5,8)}$.

Dampak negatif pembangunan KEK Mandeh terhadap kualitas perairan pesisir hanya dapat diketahui dengan membandingkan kualitas air saat itu dengan kualitas air saat ini. Untuk itulah maka kualitas air perairan pesisir KEK Mandeh saat ini, terutama nutrien dan keberadaan fitoplankton menjadi sangat penting untuk diketahui dan oleh karenanya penelitian ini dilaksanakan.

Nutrien merupakan unsur-unsur penting yang diperlukan tumbuhan, termasuk fitoplankton untuk kehidupannya. Di perairan, kehidupan fitoplankton sangat dipengaruhi oleh konsentrasi nitrogen dan fosfor. Kehidupan fitoplankton di perairan tawar menurut Schlinder ${ }^{(9)}$ dibatasi oleh konsentrasi unsur fosfor; di perairan pesisir menurut Antia, et.al ${ }^{(10)}$ dan Ryther, J. H. et.al ${ }^{(11,12}$ dibatasi oleh konsentrasi unsur nitrogen; dan di lautan menurut Thomas ${ }^{(12)}$ dan McCarthy ${ }^{(13)}$, dibatasi oleh unsur nitrogen.

Secara alamiah konsentrasi nutrien di perairan pesisir dan laut sangat bervariasi, tergantung letak geografis dan musim. Konsentrasi nutrien di perairan laut di sekitar khatulistiwa, sepanjang tahun cenderung rendah dan tidak fluktuatif, yang terjadi karena di sekitar khatulistiwa proses fotosintesis terjadi sepanjang tahun, dan penambahan zat hara dari dasar laut akibat pengadukan jarang terjadi. Di pesisir di sekitar khatulistiwa terutama sekitar muara sungai, konsentrasi nutrien cenderung selalu tinggi yang terjadi karena air sungai yang masuk ke pesisir membawa nutrien. Fenomena inilah yang menyebabkan estuari menjadi perairan yang subur, karena estuari merupakan pintu masuk air sungai ke pesisir. Sementara itu konsentrasi nutrien di perairan laut di daerah dengan empat musim sangat fluktuatif karena setiap tahun pada musim gugur dan dingin selalu terjadi pengadukan air yang membawa nutrien dari bawah ke permukaan air, sedangkan pemakaian nutrien oleh fitoplankton melalui fotosintesis hanya terjadi pada musim semi dan panas $^{(14)}$.

Fitoplankton menyerap unsur nitrogen dalam bentuk Nitrat- $\mathrm{N}$ dan Amonium $\left(\mathrm{NH}_{4}^{+}\right)-\mathrm{N}$, dan 
menyerap unsur fosfor dalam bentuk orthofosfat. Pada umumnya perairan laut mengandung nitratnitrogen $0-0,420 \mathrm{mgN} / \mathrm{l}$ dan orthofosfat-fosfor sekitar $0,093 \mathrm{mg} \mathrm{P} / \mathrm{/}^{(15)}$. Hendersen dan Markland mengungkapkan bahwa Algal bloom akan mudah terjadi pada perairan yang mengandung 0,30 mg.N/l dan 0,010 mg.P//(16).

Plankton adalah mikroorganisme yang hidup melayang-layang di dalam air dan bergerak bukan atas kekuatan sendiri tetapi tergantung gerak air. Plankton terdiri dari plankton tumbuhan atau fitoplankton, dan plankton hewan atau zooplankton $^{(17)}$. Fitoplankton secara alami adalah makanan utama zooplankton, dan bersama fitoplankton, zooplankton menjadi makanan utama pisces (ikan). Pertumbuhan dan perkembangan komunitas fitoplankton dalam sebuah perairan pada umumnya berbanding lurus dengan konsentrasi nutrien terlarut; sehingga tidak mengherankan jika semakin tinggi konsentrasi nutrien terlarut, komunitas fitoplankton semakin cepat tumbuh dan berkembang mencapai kelimpahan yang tinggi. Yang perlu di perhatikan adalah bahwa komunitas fitoplankton di lokasi berbeda memiliki struktur komunitas (disusun oleh jenis dengan komposisi) yang berbeda.

Tilman ${ }^{(18)}$ dan Smith ${ }^{(19)}$ mengungkapkan bahwa dominasi fitoplankton dalam komunitasnya lebih ditentukan oleh perbandingan konsentrasi nutrien terlarut. Hal ini disebabkan karena setiap jenis fitoplankton memberikan respon yang berbeda terhadap perbandingan nutrien terlarut. Di perairan, dominasi fitoplankton juga ditentukan oleh kebiasaan makan zooplankton. Beberapa publikasi mengungkapkan bahwa zooplankton mampu memilih fitoplankton (selective feeding) berdasarkan jenis, bentuk, dan ukurannya(20,21). Hal tersebut mengakibatkan jenis fitoplankton yang disukai atau dipilih oleh zooplankton; meskipun nutrien berlimpah akan tertekan pertumbuhannya, sedangkan jenis yang tidak disukai atau tidak dipilih akan tetap eksis dan tumbuh subur untuk mendominasi komunitasnya ${ }^{(22)}$.

\subsection{Tujuan.}

Tujuan penelitian ini adalah mengetahui kualitas perairan pesisir Bukit Ameh, KEK Mandeh di Kabupaten Pesisir Selatan.

\section{BAHAN DAN METODE}

Penelitian ini dilaksanakan dengan mengambil sampel/contoh air di pesisir Bukit Ameh KEK Mandeh pada 18 Oktober 2018. Contoh air diambil di lima tempat pengambilan sampel (TPS) yaitu AL-1, AL-2, AL-3, AL-4 dan AL-5 (Gambar 1). Guna mencapai tujuan penelitian maka dilakukan survei untuk mengukur temperatur, kecerahan, $\mathrm{pH}$, salinitas, dan oksigen terlarut; serta mengambil contoh air sebanyak $500 \mathrm{ml}$ untuk dianalisis konsentrasi nutrien dan 40 liter yang disaring menjadi 100 $\mathrm{ml}$ untuk dianalisis jenis dan kelimpahan plankton. Untuk mengambil air digunakan VarDorn water samples dan untuk menyaring air digunakan plankton net no. 25.

Di laboratorium, nutrien ditentukan dengan metode kolorimetri(23) dan plankton diidentifikasi dan dihitung menggunakan mikroskop ${ }^{(24)}$.

\section{HASIL DAN PEMBAHASAN}

Hasil analisis fisik dan kimia air dari 5 tempat pengambilan sampel (TPS) yakni AL1-AL5 disajikan pada Tabel 1 sedangkan jenis dan kelimpahan fitoplankton dari TPS yang sama disajikan pada Tabel 2.

\subsection{Fisik dan Kimia}

Tabel 1 menunjukkan bahwa nilai suhu, kekeruhan, $\mathrm{pH}$, dan salinitas di lima TPS tidak menunjukkan adanya perbedaan yang mencolok dan nilai-nilai tersebut adalah kisaran nilai yang umum terjadi di perairan daerah tropis dan biasa diperoleh peneliti perairan pesisir dan laut di Indonesia ${ }^{(25,26)}$. Perbedaan antara nilai terendah dengan tertinggi pada parameter tersebut, diduga tidak akan memberikan pengaruh yang nyata pada kehidupan organisme perairan, terutama plankton dan ikan.

Tabel 1. Konsentrasi beberapa parameter kualitas air

\begin{tabular}{|r|l|c|c|c|c|c|}
\hline \multirow{2}{*}{ No } & \multirow{2}{*}{ Parameter } & \multicolumn{5}{|c|}{ Tempat Pengambilan Sampel (TPS) } \\
\cline { 3 - 7 } & & $\mathrm{AL}-1$ & $\mathrm{AL}-2$ & $\mathrm{Al}-3$ & $\mathrm{Al}-4$ & $\mathrm{AL} 5$ \\
\hline 1 & Temperatu $\left({ }^{\circ} \mathrm{C}\right)$ & 30,5 & 30,5 & 29,9 & 30,9 & 30,7 \\
\hline 2 & Kekeruhan $(\mathrm{NTU})$ & 0,566 & 0,436 & 0,504 & 0,537 & 1,70 \\
\hline 3 & Kecerahan $(\mathrm{m})$ & 10 & 8 & 5 & 5 & 2 \\
\hline 4 & $\mathrm{TSS}(\mathrm{mg} / \mathrm{L})$ & 4,0 & 2,0 & $<1$ & 13,0 & 4,0 \\
\hline & & & & & & \\
\hline 5 & $\mathrm{pH}$ & 8,46 & 8,66 & 8,74 & 8,63 & 8,64 \\
\hline 7 & $\mathrm{Salilitas}(\%)$ & 33,0 & 32,0 & 33,0 & 32,0 & 27,0 \\
\hline 8 & $\mathrm{DO}_{(\mathrm{mg} / \mathrm{L})}$ & 7,3 & 7,1 & 7,2 & 7,1 & 6,4 \\
\hline 9 & $\mathrm{BOD}_{5} \mathrm{mg} / \mathrm{L}$ & 3,0 & 3,2 & 3,7 & 3,5 & 3,3 \\
\hline 10 & $\mathrm{NH}_{3}-\mathrm{N}(\mathrm{mg} / \mathrm{L})$ & $<0.054$ & $<0.054$ & $<0.054$ & $<0.054$ & $<0.054$ \\
\hline 11 & $\mathrm{NO}_{3}-\mathrm{N}(\mathrm{mg} / \mathrm{L})$ & 0,90 & 0,80 & 0,80 & 0,90 & 0,90 \\
\hline 12 & $\mathrm{PO}_{4}-\mathrm{P}(\mathrm{mg} / \mathrm{L})$ & $<0.093$ & $<0.093$ & $<0.093$ & $<0.093$ & $<0.093$ \\
\hline 13 & $\mathrm{H}_{2} \mathrm{~S}(\mathrm{mg} / \mathrm{L})$ & $<0.0007$ & $<0.0007$ & $<0.0007$ & 0,001 & $<0.0007$ \\
\hline
\end{tabular}

Pada saat yang sama, perairan tersebut mengandung Dissolved Oxygen (DO) 6,40-7,30 $\mathrm{mg} / \mathrm{l}$. Konsentrasi oksigen terlarut yang berkisar antara 6,40-7,30 $\mathrm{mg} / \mathrm{l}$ tersebut adalah kisaran konsentrasi yang sangat baik untuk menunjang kehidupan organisme air. Pada umumnya, organisme air seperti ikan dapat hidup normal pada perairan dengan konsentrasi oksigen terlarut lebih dari $3 \mathrm{ppm}^{(27)}$. Perlu diperhatikan pula bahwa konsentrasi DO hasil kajian ini $(6,40$ 
$-7,30 \mathrm{mg} / \mathrm{l}$ ) adalah lebih besar (baik) daripada yang dilaporkan Putra et al. pada 2013. Putra et al. melaporkan bahwa pada Tahun 2013, konsentrasi DO di di sekitar TPS AL-5 hanya sekitar $4,3 \mathrm{mg} / \mathrm{I}^{(28)}$. Fenomena ini mengindikasi kan telah terjadinya perbaikan kualitas perairan, yang disebabkan oleh berhentinya kegiatan yang diduga menjadi sumber pencemar, yakni budidaya ikan dengan Keramba Jaring Apung (KJA) di lokasi tersebut.

Selanjutnya, Tabel 1 menunjukkan bahwa pada saat kajian ini dilakukan konsentrasi amoniak-N sekitar $0,054 \mathrm{mg} / \mathrm{l}$, nitrat-N antara 0,80-0,90 mg/l. dan ortofosfat-P adalah 0,093 $\mathrm{mg} / \mathrm{l}$. Jika nilai konsentrasi ketiga hara tersebut diacukan pada baku mutu air laut yang berlaku maka nilai ketiga parameter hara tersebut sudah jauh lebih besar dari baku mutu air laut untuk biota(29). Baku mutu air laut untuk biota laut adalah 0,03 mg/l untuk amoniak-N, 0,008 mg/l untuk nitrate- $\mathrm{N}$ dan 0,015 untuk ortofosfat- $\mathrm{P}$. Dengan demikian, dapat disimpulkan bahwa secara umum perairan pesisir Bukit Ameh sudah dalam kondisi tercemar nutrien; dan dengan konsentrasi nitrogen dan fosfor yang ada sudah rawan mengalami algal bloom ${ }^{(16)}$. Meskipun saat studi ini dilakukan kualitas air pesisir Bukit Ameh dalam kondisi tercemar, namun sebenarnya kualitas tersebut masih lebih baik daripada kondisi di Tahun 2013, dimana Putra et al. ${ }^{(28)}$ melaporkan bahwa konsentrasi amonia- $\mathrm{N}$ sekitar $0,040 \mathrm{mg} / \mathrm{l}$, dan konsentrasi ortofosfat-P sekitar $0,30 \mathrm{mg} / \mathrm{l}$.

$\mathrm{Di}$ atas telah dijelaskan bahwa unsur nitrogen menjadi faktor pembatas bagi kehidupan fitoplankton di pesisir dan laut. Untuk mengetahui keterkaitan antara kualitas air dan kelimpahan fitoplankton disusun Tabel 2 yang memuat hasil penelitian ini dan datadata beberapa publikasi lain (28,30-38). Tabel 2 menunjukkan bahwa konsentrasi nitratnitrogen di Bukit Ameh ada 0,80-0,90 mg/l. Konsentrasi nitrat- $\mathrm{N}$ tersebut lebih besar dari nilai di pesisir KEK Sorong ${ }^{(30)}$, Pesisir Matak ${ }^{(31)}$, Pesisir Kabil(32), Teluk Gerupuk(33), Pesisir Pariaman(34), dan Teluk Bungus-Padang( ${ }^{(35)}$. Konsentrasi nitrat-nitrogen yang lebih tinggi dari pesisir Bukit Ameh ditemukan di perairan Pulau Kelapa(36), perairan pesisir Tarakan(37), dan pesisir Pulau Panyengat-Riau(38).

Selanjutnya juga diketahui konsentrasi ortofosfat-P di Pesisir Bukit Ameh yang 0,093 mg/l juga lebih besar daripada Pesisir Sorong ${ }^{(30)}$, Selat Matak(31), Pesisir Kabil(32), perairan Pesisir Pariaman-Sumbar( ${ }^{(34)}$, Teluk Bungus-Padang( ${ }^{(35)}$ dan perairan Pulau Kelapa ${ }^{(36)}$. Konsentrasi ortofosfat-P yang lebih tinggi dari pesisir Bukit Ameh ditemukan di perairan Pesisir Tarakan yang $0,08-0,15 \mathrm{mg} / \mathrm{I}^{(37)}$, Teluk Gerupuk ${ }^{(33)}$, dan Panyengat $\mathrm{Riau}^{(38)}$. Secara umum, perairan yang mengadung nutrien lebih tinggi diakui sebagai perairan yang lebih subur. Dengan demikian maka perairan pesisir Bukit Ameh lebih subur dari perairan pesisir Sorong, Selat Matak, Pesisir Kabil, Pesisir Pariaman dan Teluk BungusPadang.

Tabel 2. Konsentrasi nutrien dan kelimpahan fitoplankton di beberapa perairan pesisir

\begin{tabular}{|c|c|c|c|}
\hline \multirow[b]{2}{*}{ Lokasi } & \multicolumn{2}{|c|}{ Nutrien } & \multirow[b]{2}{*}{$\begin{array}{l}\text { Fitoplankton } \\
10^{3} \text { sel//M }\end{array}$} \\
\hline & $\begin{array}{l}\text { Nitrate } \\
\mathrm{mg} / \mathrm{l}\end{array}$ & $\begin{array}{c}\text { Orthofosfat } \\
\mathrm{mg} / \mathrm{l}\end{array}$ & \\
\hline Pesisir Bukit Ameh & $0,800-0,900$ & 0,093 & $795-3.909$ \\
\hline Mandai Pessel(28) & $0,300-0,400$ & $0,300-0,500$ & 12.918 \\
\hline Pesisir Sorongl(30) & $0,015-0,090$ & 0,002 & $1.231-9.895$ \\
\hline Selat Matak ${ }^{(31)}$ & ttd & ttd & $17.500-23.100$ \\
\hline Pesisir Kabil(32) & $0,001-0,084$ & $0,024-0,056$ & - \\
\hline Teluk Gerupuk ${ }^{(33)}$ & $0,129-0,625$ & $0,014-0,426$ & $619-7.459$ \\
\hline Pesisir Pariaman ${ }^{(34)}$ & $0,009-0,034$ & $0,018-0,030$ & - \\
\hline Teluk Bungus ${ }^{(35)}$ & $0,020-0,250$ & $0,050-0,080$ & - \\
\hline Pulau Kelapa ${ }^{(36)}$ & $0,040-0,069$ & 0,002 & $23.190-639.410$ \\
\hline Pesisir Tarakan (37) & $2,260-5,850$ & $0,080-0,150$ & - \\
\hline Pulau Panyengat ${ }^{(38)}$ & $1,213-1,618$ & $0,065-0,173$ & 10.371 \\
\hline
\end{tabular}

\subsection{Fitoplankton}

Hasil identifikasi dan penghitungan contoh fitoplankton yang diambil pada 18 Oktober 2018 disajikan pada Tabel 3. Tabel 3 mengisyaratkan bahwa perairan pesisir Bukit Ameh dihuni oleh paling sedikit 23 jenis (species) fitoplankton dari 4 kelas yakni kelas Bacillariophyceae sebanyak 18 jenis; Chrisophyceae sebanyak 3 jenis; Cyanophyceae sebanyak 3 jenis dan Dinophyceae sebanyak 3 jenis.

Satu hal yang perlu mendapat perhatian adalah bahwa meskipun pengambilan sampel dilakukan pada waktu yang hampir sama (hanya beda 1-2 Jam), namun tidak semua jenis fitoplankton ditemukan di setiap TPS. Pada Tabel 2 nampak (a) 8 jenis fitoplankton hanya ditemukan di 1 TPS contohnya Asterionella sp. dari Kelas Bacillariophyceae; (b) 3 jenis yang ditemukan di 2 TPS contohnya Ceratium sp. dari Kelas Dinophyceae; (c) 2 jenis yang ditemukan di 4 TPS contohnya Biddulphia sp. dari Kelas Bacillariophyceae; dan (d) 10 jenis yang ditemukan di semua TPS seperti Trichodesmium sp. (Cyanophyceae). Fenomena ini tidak menunjukkan bahwa jenis fitoplankton yang tidak teridentifikasi di suatu TPS memang tidak ada di TPS lain; seperti Asterionella sp. yang hanya teridentifikasi di $\mathrm{AL}-4$, dan Ceratium sp. yang nampak di $A L-3$ dan $A L-4$ tidak berarti tidak ada di TPS lain.

Garno $^{(36)}$ mengungkapkan bahwa kenyataan di atas diduga terjadi karena populasi jenis tersebut di TPS tertentu sangat sedikit sehingga tidak ikut terambil sebagai sampel. Fenomena ini bisa terjadi disaat pengambilan contoh di lapangan dan atau di laboratorium. Pengambilan contoh di lapangan dengan plankton net dapat 
menyebabkan fitoplankton berukuran lebih kecil dari mata jaring dengan mudah lolos sehingga tidak ikut terambil sebagai sampel; apalagi jika memang populasinya kecil. Sedangkan di laboratorium (meskipun peluangnya kecil) akan terjadi jika identifikasi dibawah mikroskop tidak cukup ulangannya sehingga fitoplankton yang populasinya kecil tidak/belum sempat terlihat ${ }^{(36)}$.

Pada Tanggal 18 Oktober 2018, kelimpahan fitoplankton di 5 TPS Pesisir Mandeh bervariasi antara 795.183-3.909.750 ind $/ \mathrm{m}^{3}$, dengan indeks dominansi bervariasi antara 0,23-0,55 (Tabel-3). Dengan nilai dominansi $D^{\prime}=0,23-0,55$ pada umumnya diartikan sebagai suatu komunitas fitoplankton yang tidak didominasi oleh salah satu jenis fitoplankton. Yang perlu diperhatikan adalah bahwa meskipun nilai indeks dominansi=D' (statistik) mengisyaratkan tidak ada jenis fitoplankton yang mendominasi komunitas tersebut, namun Tabel 3 dengan jelas (mencolok) menunjukkan bahwa populasi Trichodesmium sp. dari Cyanophyceae di setiap TPS jauh lebih tinggi daripada populasi jenis yang lain. Populasi Trichodesmium sp. di lima TPS tercatat bervariasi antara 42,7-73,2\%, dengan populasi tertinggi di TPS-1 yang 2.162.994 ind $/ \mathrm{m}^{3}$ dan terendah di TPS-4 yang 522.102 ind $/ \mathrm{m}^{3}$. Dengan demikian, dapat dikatakan bahwa komunitas fitoplankton di perairan pesisir Mandeh didominasi oleh Trichodesmium sp.

Populasi Trichodesmium sp. yang ditemukan tinggi di perairan pesisir adalah hal yang biasa terjadi. Trichadesmium sp. dilaporkan pernah mendominasi perairan Teluk Kao-Halmahera, dengan populasi $3.900 \times 10^{3}$ ind $/ \mathrm{m}^{3}$; yang merupakan $90 \%$ kelimpahan fitoplankton di teluk itu(39). Tingginya populasi Trichodesmium di perairan pesisir adalah karena selain disebabkan oleh tingginya unsur hara di pesisir yang selalu mendapat suplai hara dari daratan; juga karena Trichodesmium $s p$. dapat mengikat unsur nitrogen langsung dari udara.

Trichadesmium sp. perlu diperhatikan karena populasinya bisa berkembang dengan cepat dan padat sehingga menyebabkan penurunan kadar oksigen yang drastis dan kematian massal pada ikan dan vertebrata. Adnan $^{(40)}$.melaporkan bahwa peledakan populasi Trichadesmium sp. telah menyebabkan kematian ikan masal di tambak udang di Lampung.

Jenis fitoplankton lain yang keberadaannya di pesisir Bukit Ameh perlu diperhatikan adalah Ceratium sp., Dinophysis sp. dan Peridinium sp. yang termasuk dalam dinoflagelata. Pada tahun 2013, keberadaan tiga jenis dinoflagelata ini sudah diketahui; dan pada saat itu populasi Ceratium sp. adalah sekitar 8,18\% Dinophysis sp. sekitar 4,54\% dan Peridinium sp. sekitar $1,81 \%$ dari total kelimpahan fitoplankton ${ }^{(28)}$.

Tabel 3. Komunitas Fitoplankton di perairan Pesisir Bukit Ameh

\begin{tabular}{|c|c|c|c|c|c|c|}
\hline \multirow{2}{*}{ No } & \multirow{2}{*}{ Organisme } & \multicolumn{5}{|c|}{ Tempat Pengambilan Sampel } \\
\hline & & Al-1 & AL-2 & AL-3 & AL-4 & AL-5 \\
\hline & BACILLARIOPHYCEAE & & & & & \\
\hline 1 & Asterionella sp. & & - & & 3.609 & \\
\hline 2 & Bacteriastrum sp. & 43.308 & 69.774 & 10.827 & 26.466 & 12.030 \\
\hline 3 & Biddulphia sp. & 9.624 & 14.436 & 6.015 & 18.045 & \\
\hline 4 & Chaetoceros sp. & 4.812 & 447.516 & 108.270 & 102.255 & 120.300 \\
\hline 5 & Corethron sp. & - & 18.045 & & & \\
\hline 6 & Coscinodiscus sp. & 54.135 & 150.375 & 32.481 & 31.278 & 24.060 \\
\hline 7 & Diatoma sp. & 1.203 & - & - & & - \\
\hline 8 & Diploneis sp. & - & - & - & 8.421 & \\
\hline 9 & Fragilaria sp. & - & - & - & 7.218 & \\
\hline 10 & Gyrosigma sp. & - & - & 2.406 & 1.203 & \\
\hline 11 & Hemiaulus sp. & - & - & - & 3.609 & \\
\hline 12 & Melosira sp. & 9.624 & 30.075 & - & 14.436 & 36.090 \\
\hline 13 & Navicula sp. & - & - & - & 60.150 & 14.436 \\
\hline 14 & Nitzschia sp. & 38.496 & 62.556 & 42.105 & 66.165 & 21.654 \\
\hline 15 & Planktoniella sp. & - & - & - & 1.203 & \\
\hline 16 & Rhizosolenia sp. & 36.090 & 38.496 & - & - & \\
\hline 16 & Tabellaria sp. & 12.030 & - & - & - & \\
\hline 17 & Thalassionema sp. & 275.487 & 317.592 & 69.774 & 56.541 & 26.466 \\
\hline \multirow[t]{2}{*}{18} & Thalassiothrix sp. & 249.021 & 281.502 & 113.082 & 176.841 & 50.526 \\
\hline & CHRYSOPHYCEAE & & & & & \\
\hline \multirow[t]{2}{*}{19} & DICTYOCHA SP. & 26.466 & 14.436 & 20.451 & 60.150 & 16.842 \\
\hline & CYANOPHYCEAE & & & & & \\
\hline \multirow[t]{2}{*}{20} & Trichodesmium sp. & 2.162 .994 & 2.424 .045 & 372.930 & 522.102 & 447.516 \\
\hline & DINOPHYCEAE & & & & & \\
\hline 21 & Ceratium sp. & & & 3.609 & 2.406 & \\
\hline 22 & Dinophysis sp. & 18.045 & 14.436 & 4.812 & 32.481 & 14.436 \\
\hline 23 & Peridinium sp. & 12.030 & 26.466 & 8.421 & 28.872 & 27.669 \\
\hline \multicolumn{2}{|c|}{ Jumlah taksa } & 15 & 14 & 13 & 20 & 12 \\
\hline & impahan $\left(\mathrm{sel} / \mathrm{m}^{2}\right)$ & 2.953 .365 & 3.909 .750 & \begin{tabular}{|l|}
795.183 \\
\end{tabular} & 1.223 .451 & 812.025 \\
\hline \multicolumn{7}{|c|}{ Indeks: } \\
\hline & Keanekaragaman $\left(\mathrm{H}^{\prime}\right)$ & 1,073 & 1,405 & 1,714 & 2,047 & 1,636 \\
\hline & Kemerataan (E') & 0,396 & 0,532 & 0,668 & 0,683 & 0,658 \\
\hline & Dominansi (D') & 0,553 & 0,412 & 0,272 & 0,223 & 0,337 \\
\hline
\end{tabular}

Keberadaan dinopflagelata harus diperhatikan, karena telah diketahui bahwa beberapa jenis dari dinoflagelata mengandung racun yang dapat dilepaskan ke dalam air dan/atau terakumulasi dalam rantai makanan. Publikasi yang ada mengungkapkan bahwa beberapa spesies dari genus dinophysis yakni Dinophysis acuta $D$. acuminate, $D$. fortii, $D$. norvegica, $D$. mitra dan D.rotundata adalah penghasil racun yang dapat menyebabkan Amnesic Shellfish Poisoning $(\mathrm{ASP})^{(39,40,42)}$.

Pembahasan Tabel 2 mengungkapkan bahwa berdasarkan konsentrasi nutriennya, perairan Pesisir Bukit Ameh memiliki tingkat kesuburan yang lebih tinggi dari perairan lainnya. Untuk mengetahui apakah tingkat kesuburan suatu perairan berdasarkan nutrien tersebut berkorelasi positif dengan kelimpahan fitoplankton di perairan tersebut. Tabel 2 juga menunjukkan bahwa secara umum kelimpahan fitoplankton di pesisir Bukit Ameh yang berkisar $795 \times 10^{3}-3.909 \times 10^{3}$ ind $/ \mathrm{m}^{3}$ adalah lebih kecil dari semua kelimpahan fitoplankton di perairan lain. Padahal konsentrasi nutrien di Pesisir Bukit Ameh lebih tinggi (subur) dari pesisir lain; kecuali Pulau Panyengat yang berdasarkan konsentrasi nutrien lebih subur daripada Bukit Ameh.

Fenomena serupa terjadi pada perairan Pulau 
Panyengat yang memiliki nutrien lebih tinggi dari Pesisir Sorong dan Pulau Kelapa namun memiliki kelimpahan fitoplankton lebih rendah. Perairan dengan konsentrasi nutrien lebih tinggi, memiliki kelimpahan lebih tinggi hanya terjadi pada Pulau Panyengat yang lebih tinggi dari pada perairan Pesisir Bukit Ameh. Fenomena ini mengisyaratkan bahwa hasil kajian lapang dari lokasi berbeda, tidak selalu menunjukkan bahwa di perairan yang lebih subur mempunyai kelimpahan fitoplankton yang lebih tinggi. Ketiadaan korelasi yang positif tersebut diduga disebabkan karena (a) struktur komunitas fitoplanton berbeda untuk tempat yang berbeda $^{(36)}$, (b) kelimpahan fitoplankton tidak hanya dipengaruhi oleh konsentrasi nutrien namun dipengaruhi pula oleh pemangsa dan faktor oseanografi lainnya ${ }^{(22)}$, (c) secara teknis dalam mengambil sampel, para peneliti menggunakan planktonet dengan nomor berbeda (mesh size berbeda); diantaranya adalah 110 $\mu \mathrm{m}^{(41)}, 80 \mu \mathrm{m}^{(42)}, 64 \mu \mathrm{m}^{(43)}$, dan $20 \mu \mathrm{m}^{(40)}$.

\section{KESIMPULAN}

Pada saat penelitian dilakukan, perairan pesisir Bukit Ameh, KEK Mandeh, Kabupaten Pesisir Selatan telah tercemar nutrient. Saat itu paling sedikit dihuni oleh 23 jenis (species) fitopankton dengan kelimpahan total 795.183$3.909 .750 \mathrm{ind} / \mathrm{m}^{3}$, yang didominasi oleh Trichodesmium $\mathrm{sp}$. dengan populasi tertinggi $2.162 .994 \mathrm{ind} / \mathrm{m}^{3}$ atau $73,2 \%$ kelimpahan total. Di perairan tersebut ditemukan Ceratium sp., Dinophysis sp. dan Peridinium sp.; yang perlu mendapat perhatian khusus karena ketiga dinoflagelata tersebut jika terjadi "Harm Algal Bloom", dapat beracun bagi organisme lain, termasuk manusia.

Pembandingan konsentrasi nutrien terlarut dan kelimpahan fitoplankton disatu perairan dengan perairan lain tidak menunjukkan adanya korelasi positif; dalam arti makin subur suatu perairan makin tinggi kelimpahan fitoplankton. Fenomena ini terjadi karena struktur komunitas fitoplankton berbeda untuk tempat yang berbeda; kelimpahan fitoplankton tidak hanya dipengaruhi oleh konsentrasi nutrien terlarut saja, namun dipengaruhi pula oleh pemangsa dan faktor oseanografi lainnya; dan secara teknis penggunaan plankton net yang berbeda mata jaring menyebabkan tingkat kelolosan yang sangat berbeda.

\section{PERSANTUNAN}

Penulis menyampaikan terima kasih yang sebesar-besarnya pada Dr. Joko P. Susanto dan drh. Wage Komarawidjaja, M.Sc. yang telah memberikan koreksi pada draft karya ilmiah ini.

\section{DAFTAR PUSTAKA}

1. Anonim. (2012). Peraturan Pemerintah Nomor 50 Tahun 2011 tentang Rencana Induk Pembangunan Kepariwisataan Tahun 20102025. Lembaran Negara RI Tahun 2011, No. 125. Sekretariat Negara. Jakarta.

2. Anonim. (2014). Perda Propinsi Sumatera Barat Nomor 3 Tahun 2014 tentang Rencana Induk Pembangunan Kepariwisataan Provinsi Sumatera Barat.

3. Anonim. (2016). Surat Bupati Pesisir Selatan nomor 050/289.VI/Bappeda-PS/2016 tertanggal 24 Juni 2016, Kawasan Bukit Emas di Nagari Carocok Anau Ampang Pulai di Kecamatan Koto XI Tarusan yang merupakan bagian dari Kawasan Mandeh diusulkan sebagai Kawasan Ekonomi Khusus (KEK) Pariwisata dengan luasan 400 ha.

4. Anonim. (2017). Feasibility Study Kawasan Ekonomi Khusus Pariwisata Mandeh. Dinas Penanaman Modal dan Pelayanan Terpadu Satu Pintu Provinsi Sumatera Barat.

5. Garno, Y.S. (2004). Bomanipulasi, Paradigma Baru Dalam Pengendalian Limbah Organik Budidaya Perikanan Di Waduk Dan Tambak Orasi IImiah Pengukuhan Ahli Peneliti Utama Bidang Manajemen Kualitas Perairan Badan Pengkajian Dan Penerapan Teknologi Jakarta, 28 April 2004.

6. Jones-Lee, A., \& Lee, G.F. (2005). Eutrophication (Excessive Fertilization). Water Encyclopedia: Surface and Agricultural Water. Wiley, Hoboken, NJ. p 107-114.

7. Gypens, N., Borges, A.V., \& Lancelot, C. (2009). Effect of eutrophication on air-sea $\mathrm{CO} 2$ fluxes in the coastal Southern North Sea: a model study of the past 50 years. Global Change Biology, 15: 1040-1056.

8. Howarth, R., Anderson, D., Cloern,J., Elfring,C., Hopkinson,C., Lapointe,B., Malone, T., Marcus, N., McGlathery, K., Sharpley, A., \&.Walker. (2000). Nutrient pollution of coastal rivers, bays, and seas. Issue in Ecology No. 7, Ecological Soc. of America, Washington, DC.

9. Schlinder, D.W. (1971). Carbon, Nitrogen an phosphorus, and the euthrophication of Freshwater Lakes. J. Phycol. 7:321-329..

10. Antia, J. K., C. D. McAllister, T.R. Parsons, K. Stephen, \& J.D.H. Strickland. (1963). Further measurements of Primary Productions using a Large-Volume plastic sphere., Limnol. Ocenogr., 8: 166-183.

11. Ryther, J. H. \& Dustan, W. M. (1971). Nitrogen, Phosphorus and Eutrophication in 
coastal Marine environment. Science 171:1008-1013.

12. Thomas, W.H. (1969). Phytoplankton zat harat enrichment experiment off Baja California and in the equatorial Pacific ocean. J.Fish. Resh. BD. Can., 26:1101-1112.

13. McCarthy, J. J. (1980). Nitrogen. Pp.191-234 in Morris (ed.), The Physiological. Ecology of Phytoplankton. Univ. California.

14. Corner, E.D.S., \& Davies A. G. (1971). Plankton as $A$ Factor in the Nitrogen and Phosphorus

15. Parsons, T.R., Takahashi, M., \& Hargrave, B. (1984). Biological Oceanographic Processes. Pergamon Press. Oxford-New York-ToromtoSydney-Paris- Frankfurt

16. Hendersen B. \& H.R. Markland. (1987). Decaying Lakes-The Origins and Control of Cultural Eutrofication. John \& Willey Sons Ltd. New York Chichester, Brisbane, Toronto, Singapura.. Theor. Angew. Limnol. Verh., 20, 68-74

17. Goldman, C.R \& Horne, A. J. (1983). Limnology. International Student Edition. McGraw-Hill, Inc. Tokyo. pp: 464

18. Tilman, D. (1977). Resource competition between planktonic algae: an Experimental theoretical approach. Ecology, 58:338-348.,

19.Smith, V.H., (1982). The nitrogen and phosphorus dependence of algal biomass lakes: an empirical and theoritical analysis. Limnol. Oceanogr., 27: 1101-1112.

20. Frost, B.W. (1980). "Grazing" In I. Morris (ed.): The physiological ecology of phytoplankton. Blackwell Scientific, Oxford.

21. James M. R, \& Forsynth D. J. (1990). "Zooplankton-phytoplankton interaction in a eutrophic lake. J. Plankton Res., 12, 455-472.

22. Garno, Y. S. (1993). Pengaruh grazing zooplankton terhadap struktur komunitas fitoplankton. Lokakarya Tekn. Konservasi Fauna. Dir. TPLH-BPPT., 159-174.

23. APHA. (1985). Standart Method for the examination of water and waste water, 16th Ed. Washinton D.C.

24. Yamaji, I. (1974). Ilustration the Marine Plankton of Japan. Osaka, Hoikusa Publishing, Japan.

25. Erlania, I.N. Radiarta \& Rasidi. (2014). Indeks Biologis Fitoplankton Sebagai Indikator Kondisi Perairan Pada Lokasi Budidaya Laut di Teluk Ambon, Maluku. Balitbang perikanan. KKP, hal: 447-454.
26. Rasidi, Radiarta, I.N. \& Erlania. (2014). Hubungan Komunitas Plankton Dengan Kondisi Kualitas Perairan Di Teluk Gerupuk, Nusa Tenggara Barat. Balitbang peikanan. KKP, hal: 521-527.

27. Boyd, E. C. (1990) Water Quality in Ponds for Aquaculture. Biirmingham Publishing Co. Birmingham, $482 \mathrm{pp}$.

28. Putra, I.B.E, Nawir, M. \& Deswati. (2014). Kelimpahan Plankton Di Kawasan Budidaya Perairan Teluk Carocok Tarusan Kecamatan Koto Xi Tarusan Kabupaten Pesisir Selatan. Jurusan Budidaya Perairan, Fakultas Perikanan dan IImu Kelautan Universitas Bung Hatta.

29. Anonim. (2004). Keputusan Menteri Lingkungan Hidup No. 51. 2004. Baku Mutu Air Laut.

30.Garno, Y.S \& Komarawidjaja, W. (2016). Kesuburan dan Keragaman Plankton di Perairan Pesisir Barat Kabupaten Sorong.

31. Garno, Y.S. \& .Komarawidjaja, W. (2015). Status Kualitas Perairan Selat Matak Kabupaten Kepulauan Anambas. J. Tek. Ling. PTL-BPPT.15(2):65-70).

32. Garno, Y.S (2000). Status kualitas Perairan Pesisir Kabil -Batam. . Prosisding Pengelolaan Limbah dan Pemulihan Kerusakan Lingkungan, DTL-BPP Teknologi, 251-260.

33. Purmaningtyas, Mujiyanto,S.E. \& Riswanto. (2019). Distribusi dan Kelimpahan Fitoplankton di Teluk Gerupuk, Nusa Tenggara Barat. Jurnal Akuatika Indonesia 4(1):24-30.

34. Merina, G., Zakaria, \& I.J. Chairul. (2016). Produktivitas Primer Fitoplankton Dan Analisis Fisika Kimia Di Perairan Laut Pesisir Barat Sumatera Barat, Jurnal Metamorfosa III (2): 112-119.

35. Fitra, F., Zakaria, I.J. Syamsuardi. (2013). Produktivitas Primer Fitoplankton Di Teluk Bungus. Jurnal Biologika Vol. 2, No. 1, 59-66.

36. Garno, Y.S. (2001). Kualitas Air dan Kelimpahan Fitoplankton di Perairan Pesisir Pulau Kelapa Kepulauan Seribu.Prosiding Marintek-Bppt: 218-231.

37. Amin, M. (2011). Studi Kadar Nitrat Dan Fospat Di Perairan Pesisir Kota Tarakan, Kalimantan Utara'. Jurnal Harpodon Borneo.8.(1): 27-34.

38. Efrizal, T. (2016). Hubungan Beberapa Parameter Kualitas Air Dengan Kelimpahan 
Fitoplankton Di Perairan Pulau Penyengat Kota Tanjung Pinang. Riau

39. Wiadnyana, N.N.; A. Sediadi; T. Sidabutar \& S.A. Yusuf. (1994). Bloom of the dinoflagellate in kao bay, north moluccas. Paper presented in ioc-westpac .

40. Adnan, Q. (1993). PSP and red tide status in Indonesia. In: Toxic Phytoplankton Blooms in the Sea ( T.J. Maeda. and Y. Shimizu, Eds.). Elsevier Science Publisher B.V., Amsterdam: 199-202.
41.Praseno D.P \& Adnan Q. (1996). Phytoplankton Community and Abundance In Some Estuaries of The Northern Coast of Java. Dir. TPLH-BPPT, Jakarta, 17-24

42. Effendi M. (1998). Penelitian Kepadatan Biota Perairan antara Pulau Tarakan dan P. Bunyu, Seminar Akuakultur secara Terpadu. Dir. TPLH-BPPT, Jakarta, 351-363.

43. Sidabutar, T. (1996). Kondisi Plankton dan Hidrologi di Perairan Seram Barat dan Sekitarnya pada Musim Timur, Seminar Maritim Selonesia. BPP Teknologi Wanhankamnas, Makkasar, 283-297. 